\title{
Puerto Rican
}

National Cancer Institute

\section{Source}

National Cancer Institute. Puerto Rican. NCI Thesaurus. Code C67112.

A person of Puerto Rican culture or orig in, reg ardless of race. 